\title{
Experiences in Transplanting Wood Ants into Plantations for Integrated Pest Management
}

\author{
JS NIELSEN ${ }^{1}$, MG NIELSEN ${ }^{2}$, CF DAMgAARD ${ }^{1}$, J OFFENBerg ${ }^{1}$ \\ 1 - Department of Bioscience, Aarhus University, DK-8600 Silkeborg, Denmark \\ 2 - Department of Bioscience, Aarhus University, DK-8000 Aarhus, Denmark
}

\section{Article History}

\section{Edited by}

Jacques Delabie, UESC, Brazil

Received

30 January 2018

Initial acceptance 20 April 2018

Final acceptance 09 August 2018

Publication date 02 October 2018

\section{Keywords}

Formica polyctena, forestry, fruit plantations, Christmas tree plantations, organic production, biological control.

\section{Corresponding author}

Joachim Offenberg,

Aarhus University

Department of Bioscience

Vejlsoevej 25, DK-8600

Silkeborg, Denmark.

E-Mail: joaf@bios.au.dk

\begin{abstract}
Ants can function efficiently as biocontrol agents in open field horticulture. Temperate wood ants can control forest pests, including species damaging forest regeneration plots and fruit plantations. Thus, they possess potential as biocontrol agents in open field horticulture, if they can persist in these systems. Here we present observations on activity and survival of wood ants transplanted from forests into different types of plantations. Mound fragments were transplanted into a conifer seedling plot, an organic and a conventional Christmas tree plantation, and into an organic apple plantation. Colonies survived at least one year in all types of plantations. In some cases, however, ants moved to new locations or migrated between mound fragments, leaving some inactive. Our compiled experiences suggest that this can be prevented by providing a minimum mound size, keeping a minimum spacing between mounds and incorporation of sand and scent marked wood pieces from donor colonies to imitate naturally occurring nests. We also observed that the ants preyed upon and significantly reduced the number of winter moth larvae (Operophtera brumata - a pest in apple and other fruit orchards) in two of four apple varieties. In conclusion, wood ants were tolerant to highly different habitat settings and will likely persist in most types of perennial horticultural systems, if managed properly. As they prey on winter moths and multiple other pest species, they are a potential new biocontrol agent for open agricultural systems.
\end{abstract}

\section{Introduction}

In Denmark, there is an increasing demand for organic and sustainably produced fruits as consumers request fruits without pesticide residues (Jensen \& Pedersen, 2015). Current supply does not meet demand as organic producers often lack efficient certified methods to deal with a number of pest species (Strandberg et al., 2015). As a consequence, yields are unstable and organic production less attractive. Also, Christmas tree production is facing an increasing demand for organically produced trees and similarly lack efficient methods to control arthropod pests (Brandt, 2015). If sustainable integrated pest management tools (IPM tools) were available to farmers, organic production would benefit and possibly increase its share and lead to a higher supply of residue free products. Efficient IPM measures could also benefit conventional growers if compatible with common conventional practices. IPM-components could add new eco-friendly tools to the conventional toolbox and in this way reduce their reliance on synthetic pesticides. Even small reductions in pesticide use could have high effects.

IPM-programs have been highly successful in closed horticultural systems. For example, arthropod based pest control has been widely implemented in greenhouse production, where most production is now based solely on biocontrol without the use of pesticides (Hajek, 2004; Calvo et al., 2015). A similar success has been observed in only few open systems as these systems are less easily controlled and since efficient broad spectrum beneficials (e.g. predators and parasitoids) that can work in these systems are still rare (Jonsson et al., 2008; Van Driesche et al., 2008). The use of ants in agroforestry and plantations is, however, a rare example 
of efficient biocontrol in open systems. For example (i) tropical weaver ants are renowned for being as efficient as, or even more efficient, than chemical pesticides in a number of plantation crops (Offenberg, 2015), (ii) Azteca ants have been identified as crucial in the biological protection of coffee in Central America (Vandermeer et al., 2010) and ant species richness increase yields of cocoa in Indonesia (Wielgoss et al., 2014).

In addition, red wood ants (Formica rufa (L.) group spp., Formicidae) are known to protect trees in mature temperate forests during severe arthropod pest outbreaks (Way \& Khoo, 1992; Stockan \& Robinson, 2016). Wood ant's ability to control prey populations is based on a number of features associated with their lifestyle. For example, (i) their high density in ant territories, (ii) their ability to communicate and cooperate that leads to efficient search and food acquisition (strong numerical response), (iii) their broad prey spectrum, and (iv) their long lived stable and sessile colonies (Stockan \& Robinson, 2016). If wood ants are able to persist not only in mature forest but also in more open and disturbed horticultural production systems, these ants could potentially become a new efficient biocontrol agent in perennial crops.

Transplantation and establishment of wood ants for pest control purposes has a long history. Early attempts of transplantations were conducted in 1862, but larger scale attempts were not made before 1926, followed by another one in 1938 (Wellenstein, 1973). After these first attempts, Gösswald (1984) transplanted colony fragments of Formica lugubris (Z.) into the Gramschatzer Forest in Germany in 1965, and recorded their survival. In addition to some buddings, 22 out of 25 fragments survived until 1973. Later, Pavan transplanted nests of $F$. lugubris from the Alps to Apennine Mountains and to the island of Sardinia, Italy, however, without providing data on survival (Gösswald, 1990). Wellenstein (1973) founded 890 new ant nests (primarily Formica polyctena (F.)) in different forest biotopes in south-west Germany. Some nests disappeared whereas others survived, and those surviving often relocated to sites with more favorable conditions. Bradley (1972) transplanted nests of Formica obscuripes (F.) into three young jack pine plantations in Manitoba, Canada in 1969. Even though some nests remained active, many relocated or merged. Finnegan (1975) transplanted F. lugubris from Italy to pine stands in Quebec, Canada, in 1973. After some merging and relocations, this resulted in 32 nests in 1973 and in 114 nests 34 years later (Storer et al., 2008). Pisarski and Czechowski (1990) transplanted nests of $F$. polyctena to Gorce National Park, Poland. Nests were spaced with a distance of 20-30 m and transplanted over several years. Nests transplanted in the same year often merged with nests from the same colony, while nests transplanted in different years did not merge. Lastly, Sorvari et al. (2014) transplanted 26 nests of Formica aquilonia (Y.) into forest areas in the Laukaa-Konnevesi region, Finland, of which 20 nests survived.
These studies mainly focused on transplantation techniques and nest survival. The effect of the ants on pests was only investigated in a single case. Wellenstein (1973) found that ant species with large numbers of individuals could reduce caterpillars and sawflies harmful to the forest by more than $50 \%$ within a radius of up to $30 \mathrm{~m}$ from the nest. Paulson and Akre (1992), however, managed to transplant the congener (but non-wood ant) Formica neoclara (E.) into pear orchards in Wenatchee, Washington. In this study, 22 of 27 transplanted nests successfully established within $4 \mathrm{~m}$ of their transplant position, and the ants were able to significantly reduce the numbers of pear psyllids (Cacopsylla pyricola (F.), Psyllidae), a pest in pear orchards. These studies, and the fact that a range of ant species have proven efficient as biocontrol agents, makes us believe that wood ants also may be suited for biological control programs.

To our knowledge, all published work on wood ant transplantations have been carried out in a forestry context, i.e., nests were transplanted from one forest to another. In addition, in only a few cases did ant transplantations stay at their original transplant position. In the following we compile observations and experiences from a number of transplantations of wood ants into plantation plots to assess if wood ants can establish and be utilized in agricultural settings. We transplanted $F$. polyctena colonies from a mature conifer forest into (i) a conifer seedling plot, (ii) two Christmas tree plantations and (iii) an apple plantation. We evaluated different transplantation techniques to identify a method where ants do not move or merge (defined as when ants from two or more nests gather in one common nest) their nests, as it will be important for growers to control the position of ant nests. We also evaluated the survival of transplanted nests to assess their performance in plantation settings and in an apple plantation we tested the ants' effect on a lepidopteran pest.

\section{Methods}

For the transplantations, we used $F$. polyctena as this wood ant species is common and because it is polygynous and polydomous. The presence of multiple queens enables the split of large mounds into multiple queenright fragments that can be distributed in a plantation at a desired density and mound size. Also, polygyny makes fragments/colonies less vulnerable to queen extinction. Their polydomous colony structure means that donor colonies can recover after the removal of some of the mounds in a colony. Thus, the same colony may repeatedly be used as a donor, especially if managed by, e.g., provision of food and protection against predators (Pisarski \& Czechowski, 1990). Polydomy also allows that all the fragments transplanted into a plantation may originate from a common colony and thus will cooperate, rather than compete. Lastly, they show flexibility to habitat types (Pisarski \& Czechowski, 1990), experience little or no interspecific ant competition and may control a number of 
pest species (Way \& Khoo, 1992); an average sized mound has been estimated to prey on 8 million insects per year (Wellenstein, 1952).

Two independent donor colonies of $F$. polyctena, several $\mathrm{km}$ apart, were identified in a conifer forest in Løvenholm, Denmark. Both colonies consisted of several adjacent nest mounds (11 and 7 mounds with a spacing from $3 \mathrm{~m}$ and up) connected by trails and with multiple queens in each mound. In total, six mounds from these two colonies were transplanted to four different plantations during three years (2014-2016).

\section{Conifer (Picea sp., Pinaceae) seedling plot}

One nest (approximately $1000 \mathrm{~L}$ ) from the first donor colony was dug up 01-05-2014. The nest was divided into buckets as 30 fragments (26-42 L in size), each containing brood, workers and nest material from all depths of the donor nest. The sandy soil in the lower part of the nest was gently searched for dealate queens, eggs and larvae. Dealate queens were kept in closed plastic cups with moist moss to keep high humidity. The fragments in the buckets were transported to a newly planted plot with $40-70 \mathrm{~cm}$ tall Picea sp. seedlings.
The seedling plot was $80 \times 120 \mathrm{~m}$ and situated approximately $250 \mathrm{~m}$ from the donor colony. Small numbers of various grasses, small herbaceous plants, taller Cytisus scoparius (L.) (Fabaceae) and Rubus idaeus (L.) (Rosaceae) were growing in the plot between the seedlings. The 30 fragments were placed in $65 \mathrm{~L}$ plastic laundry baskets (D48 x $\mathrm{H} 65 \mathrm{~cm}$ ) that were dug into the ground with an approximate spacing of $10 \mathrm{~m}$ (Fig 1). The baskets had plenty of holes on the sides allowing the ants to dig sideward into the surrounding soil and holes in the bottom for drainage (Fig 2). The design was used in the hope that nests could easily be removed again in one piece by lifting up the basket from the soil (for future commercial management and production). Together with the transplanted fragment, the baskets were filled with additional conifer needles collected from the forest floor in the mature forest and one dealate queen was supplied to each fragment. All fragments were supplied with a plastic feeding box (140x105x75 mm) containing ad libitum wet cat food and sugar dough (Ambrosia ${ }^{\circ}, 85.5 \%$ sucrose) served in small plastic cups $(3 \mathrm{cL})$ and with a $1.5 \mathrm{~L}$ plastic bottle with water accessible via a Vattex cloth (cotton based product used in greenhouses to conduct water). Food and water were supplied throughout the summer until the following autumn.

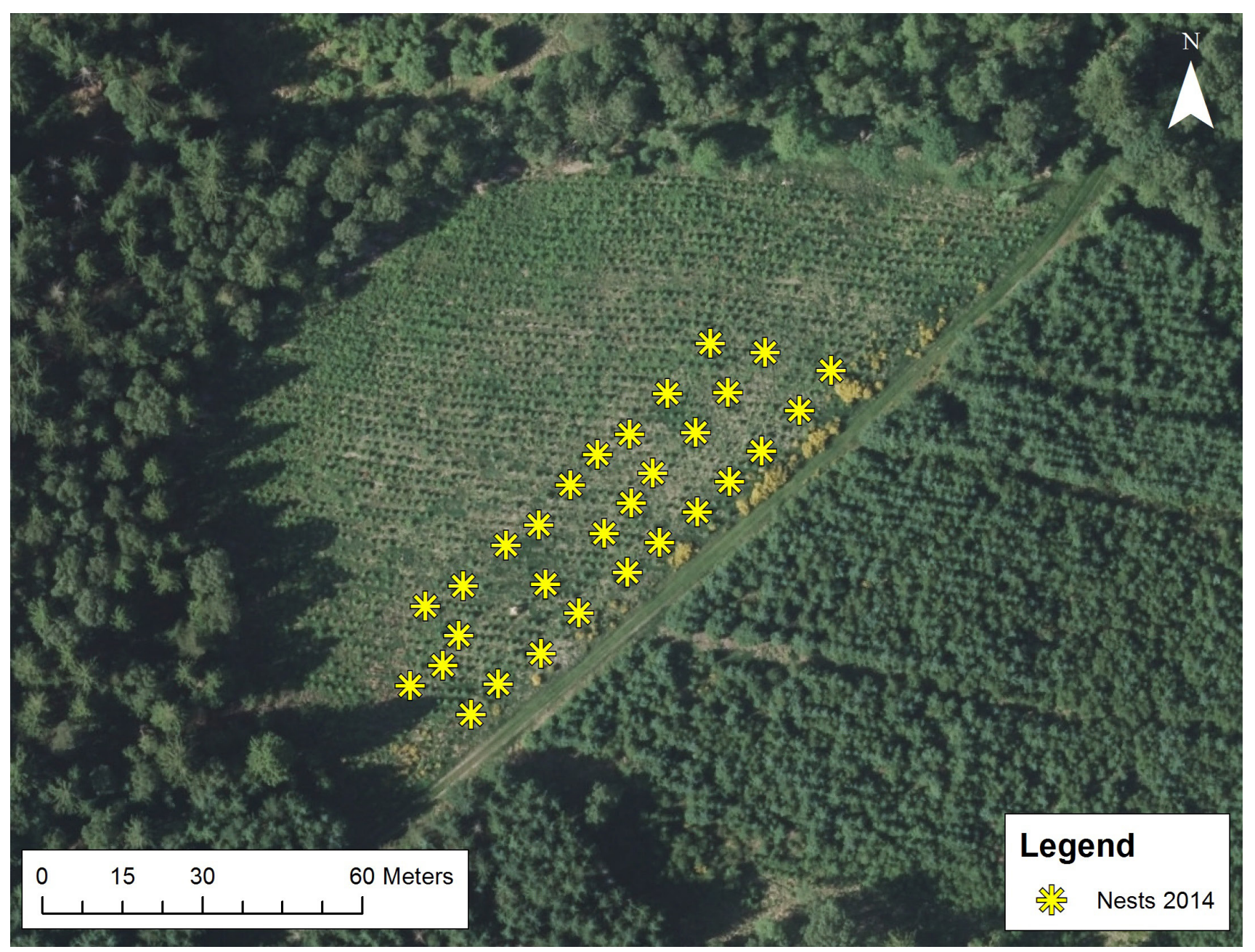

Fig 1. The conifer seedling plot. Asterisks indicate the positions of the artificial transplant nests. 


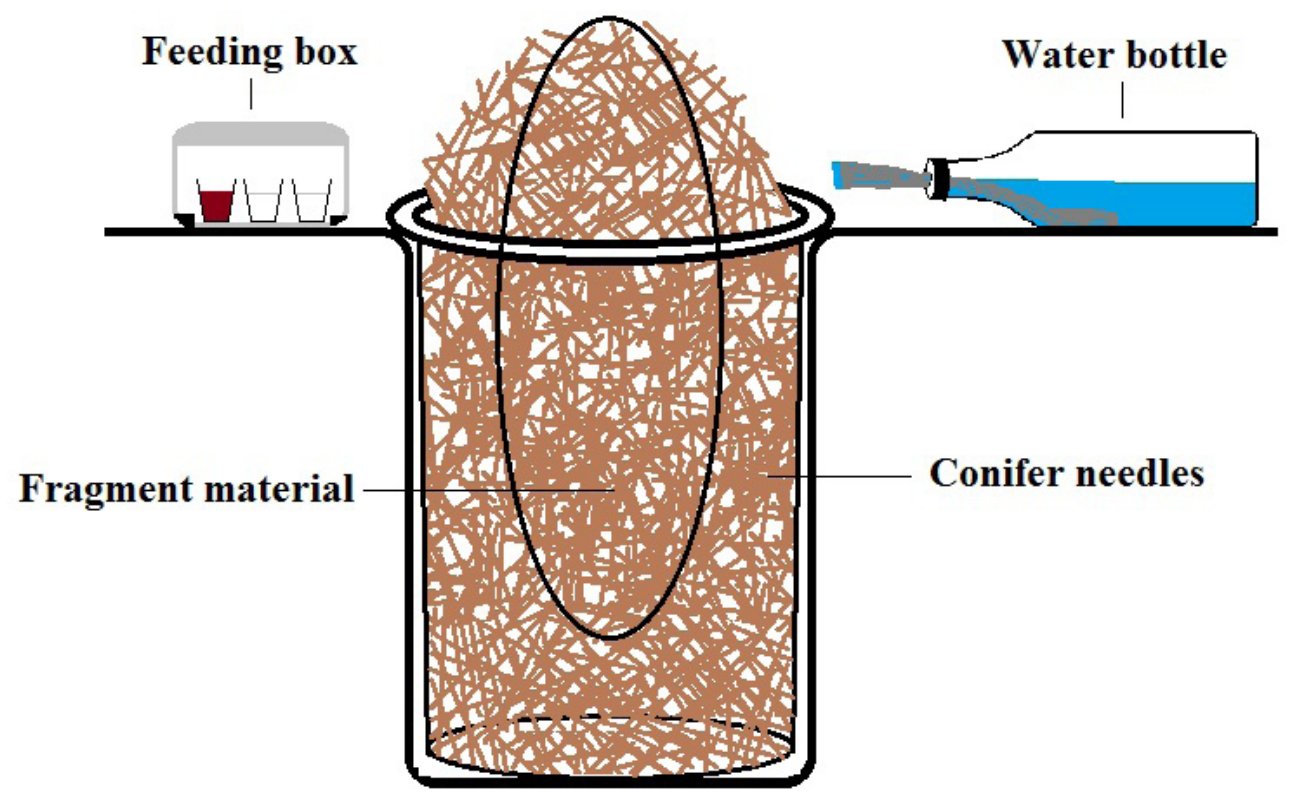

Fig 2. Artificial nest design for the first transplantation to the conifer seedling plot.

As all fragments from the first transplantation left their artificial nests within a month (see Results) another transplantation into a modified artificial nest design was conducted 04-06-2014. This time, another mound (approximately $700 \mathrm{~L}$ ) from the same donor colony was fragmented in the same way into $12,36 \mathrm{~L}$ fragments. Additionally, 11 nests that had abandoned their artificial nests after the first transplantation (to build a new one in the surroundings- see Results) were also transplanted back into an artificial nest, using the new nest design. In the new design, fragments were placed in the same type of baskets as in the first transplantation. This time, inspired by the structure of the donor mounds, with a 10-15 cm layer of sandy soil in the bottom (for drainage), a piece of wood (for brood and queen protection, approximate diameter $=10 \mathrm{~cm}$, length $30 \mathrm{~cm}$ ) supplied inside the fragment and pieces of bark on top of the conifer needles to protect against rain during establishment (Fig 3). Again, all fragments were supplied with food and water as above except that cat food was served directly on the artificial nests and the cloths in the water bottles were exchanged with dish cloths. Ants that moved out of their artificial nests were similarly supplied with food and water, once they established on a new spot.

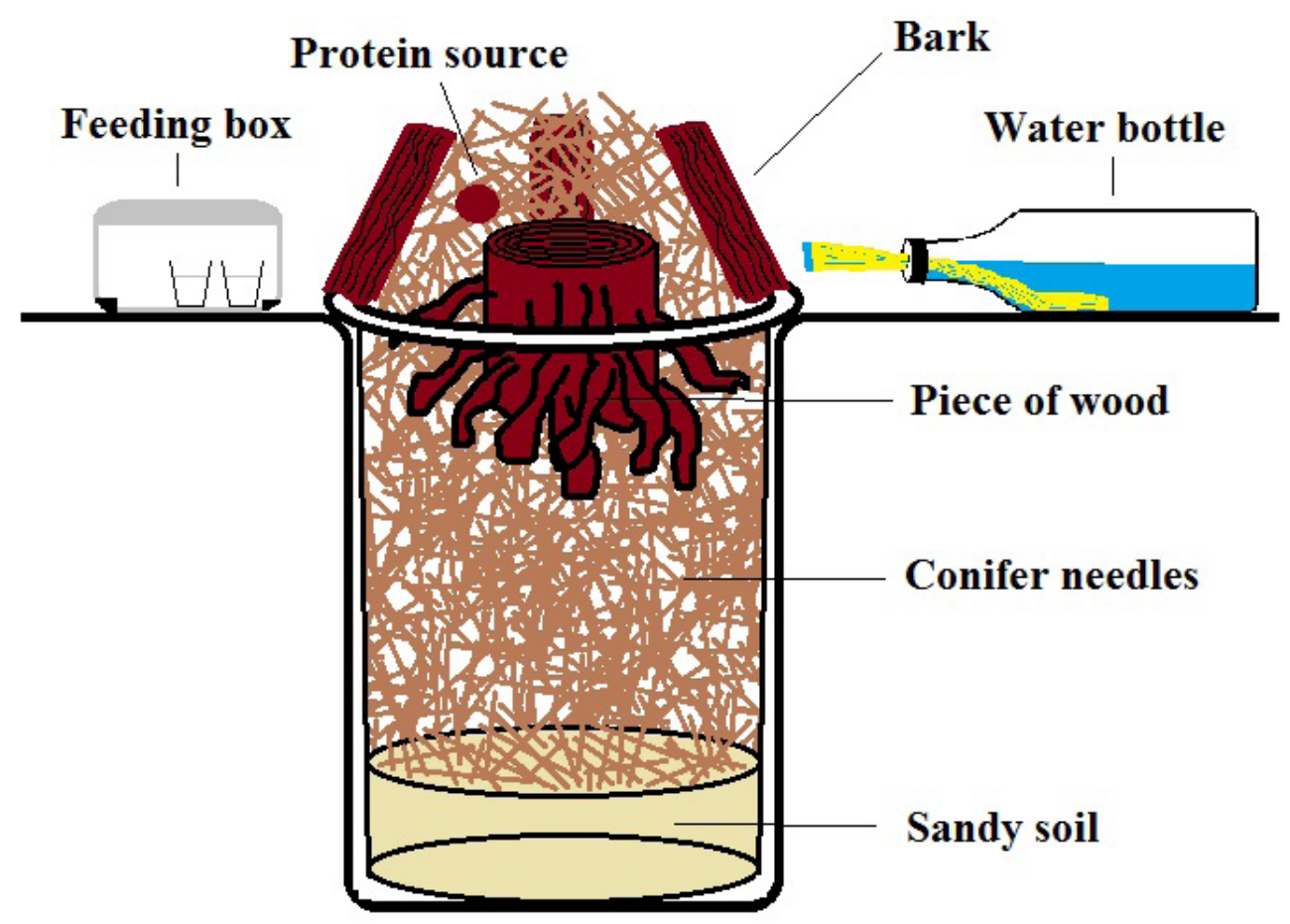

Fig 3. Artificial nest design for the second transplantation to the conifer seedling plot. 


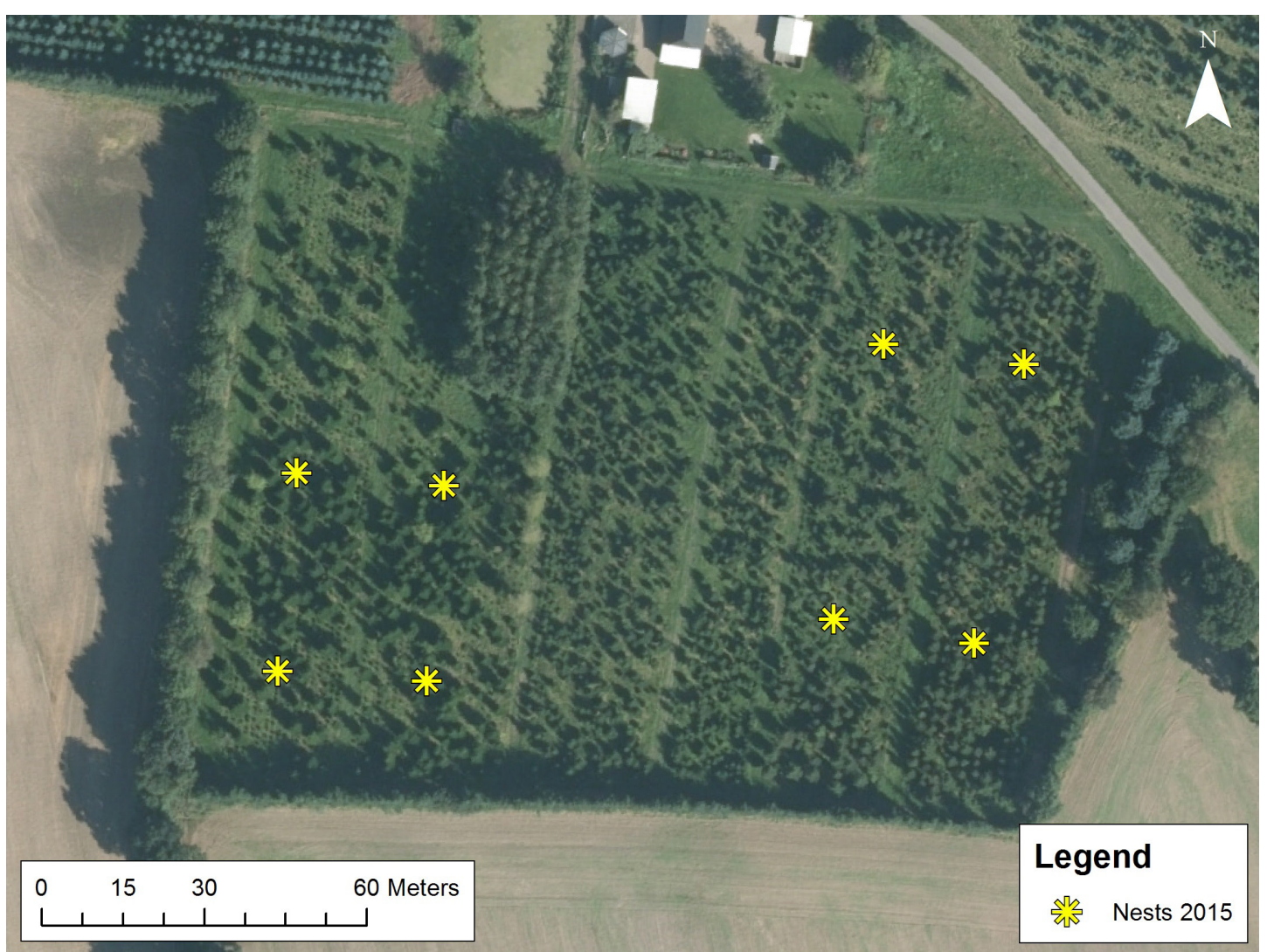

Fig 4. The organic Christmas tree plantation. The Christmas trees surrounding the four nests to the left are primarily Abies nordmanniana, and the trees surrounding the four nests to the right are primarily Picea abies. Asterisks indicate the positions of the artificial transplant nests.

\section{Christmas tree plantations}

Ants were transplanted into two different Christmas tree plantations; an organic and a conventional. The organic one was a 3-hectare plantation in Veng, Denmark, mostly composed of Picea abies (L.) in one part and Abies nordmanniana (S.) (Pinaceae) in the other. Trees were of mixed age, spanning between 0.2 and $6 \mathrm{~m}$ in height, and were spaced with a distance of 1 to $3 \mathrm{~m}$ (Fig 4). This way they created both sunny and shaded areas. Neither insecticides nor herbicides were used, but sheep were used for grazing. Dominating herbs and grasses were Festuca rubra (L.), (Poaceae) Lolium perenne (L.) (Poaceae), Cirsium vulgare (S.) (Asteraceae) and Urtica dioica (L.) (Urticaceae).

The conventional plot was a 1.6-hectare $A$. nordmanniana plantation with 2-3 years old trees (0.3-1.6 m in height) arranged with a $1.1 \mathrm{~m}$ spacing (Fig 5). Normally, the area was treated with the herbicides DFF ${ }^{\circ}$, Roundup ${ }^{\circledR}$ and the insecticide Mospilan $\AA$, but these treatments were abandoned in the 0.5 -hectare area where ants were transplanted. Plant composition and vegetation height were homogenous and dominated by Equisetum arvense (L.) (Equisetaceae), interspersed with Agrostis capillaris (L.) (Poaceae) and Cirsium arvense (L.) (Asteraceae). The small trees and low vegetation provided plenty of sun, but shaded areas were also available under the vegetation. The area faced tall trees to the north and the east, but was exposed to wind from south and west.
In spring 2015, two medium sized mounds, one from each donor colony, were each split into eight queenright 90 L fragments of upper nest material and eight $26 \mathrm{~L}$ fragments of the lower sandy soil nest material. The nest material from one donor colony was transported by car to one of the two Christmas tree plantations. Here, each of the sandy soil fragments were placed in a hole (diameter $50 \mathrm{~cm}$, depth 15 $25 \mathrm{~cm}$ ) dug in the ground and with a spacing of minimum $25 \mathrm{~m}$ between holes in the organic plantation and a spacing of $15-20 \mathrm{~m}$ in the conventional (different spacing were due to the different sizes of the two plantations). On the sandy soil, we placed a piece of old wood (diameter $=20 \mathrm{~cm}$, height $=30 \mathrm{~cm}$ ) that had previously been lying on the donor-nest mound surface for at least 10 days prior to the transplantation (to make the ants accustomed to the wood and allowing them to scent mark it). Lastly, the upper nest material fragment was loosely applied on top of the wood, allowing the ants to arrange the material themselves (Fig 6). Nests were placed in selected spots that were (i) exposed to direct sun, (ii) with low risk of standing water, and (iii) at a minimum distance of $3 \mathrm{~m}$ from other natural occurring ant nests (Kilpeläinen et al., 2008; Sorvari et al., 2014). Fragments were supplied with sugar dough in perforated cash boxes (to prevent larger animals from eating it) and water in open plastic boxes (SmartStore, $21 \times 17 \times 15 \mathrm{~cm}$ ). Protein was only available from natural sources.

A summary of the methods used to transplant mounds into the different plantations are provided in Table 1. 


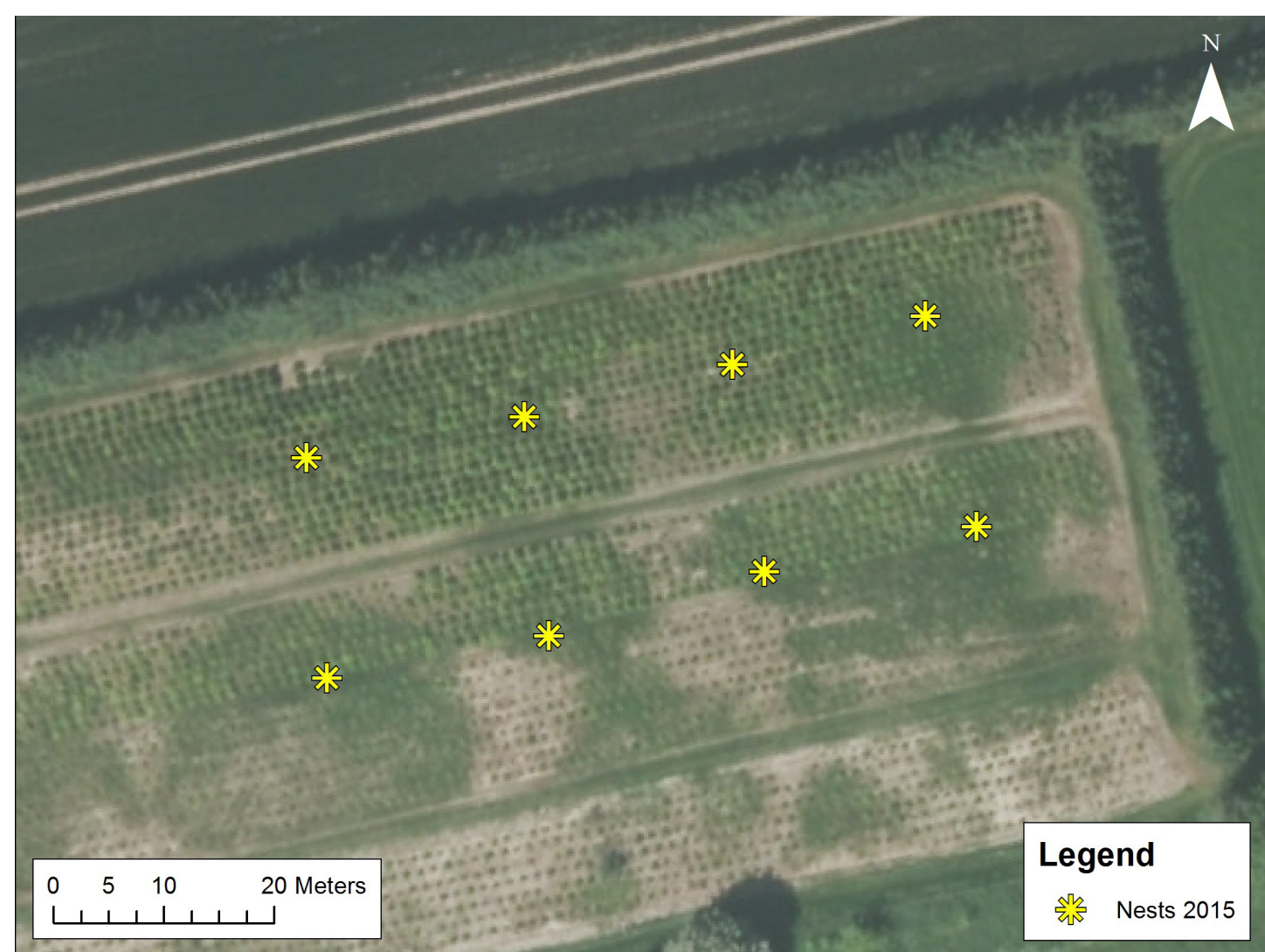

Fig 5. The conventional Christmas tree plantation. Asterisks indicate the positions of the artificial transplant nests.

\section{Apple plantation}

Lastly, ants were transplanted into a 1.3-hectare organic apple (Malus pumila (M.), Rosaseae) plantation (Æbletoften) in Tirstrup, Denmark (Fig 7). Eleven apple varieties of sevenyear-old trees arranged in rows $(1 \mathrm{~m}$ between trees and $3.5 \mathrm{~m}$ between rows) were grown in the plantation. Vegetation strips in the middle and surrounding the plantation (used to attract beneficials) created plant diversity and variation in vegetation height. The most common herbs and grasses were Poa spp. (Poaceae), Taraxacum sp. (Asteraceae), Dactylis glomerata (L.) (Poaceae), Elytrigia repens (L.) (Poaceae), Tanacetum vulgare (L.) (Asteraceae), Anthriscus sylvestris (L.) (Apiaceae) and $C$. arvense. Grass between rows was mowed one to two times every second week during summer. Forests to the west and east of the plantation provided some wind cover from these directions. Even though the area was drained by drainpipes, standing water was sometimes building up in spring and autumn, which caused flooding risk of the underground parts of ant nests. No conifer trees were present in the plantation.

In 2015, eight $90 \mathrm{~L}$ fragments originating from a single nest mound from one donor colony were transplanted to the plantation using the same methods as in the Christmas tree plantations (including water supply). The spacing between nests was 15-20 m. In 2016, another mound from one donor colony was split into four fragments of twice the size $(180 \mathrm{~L})$.

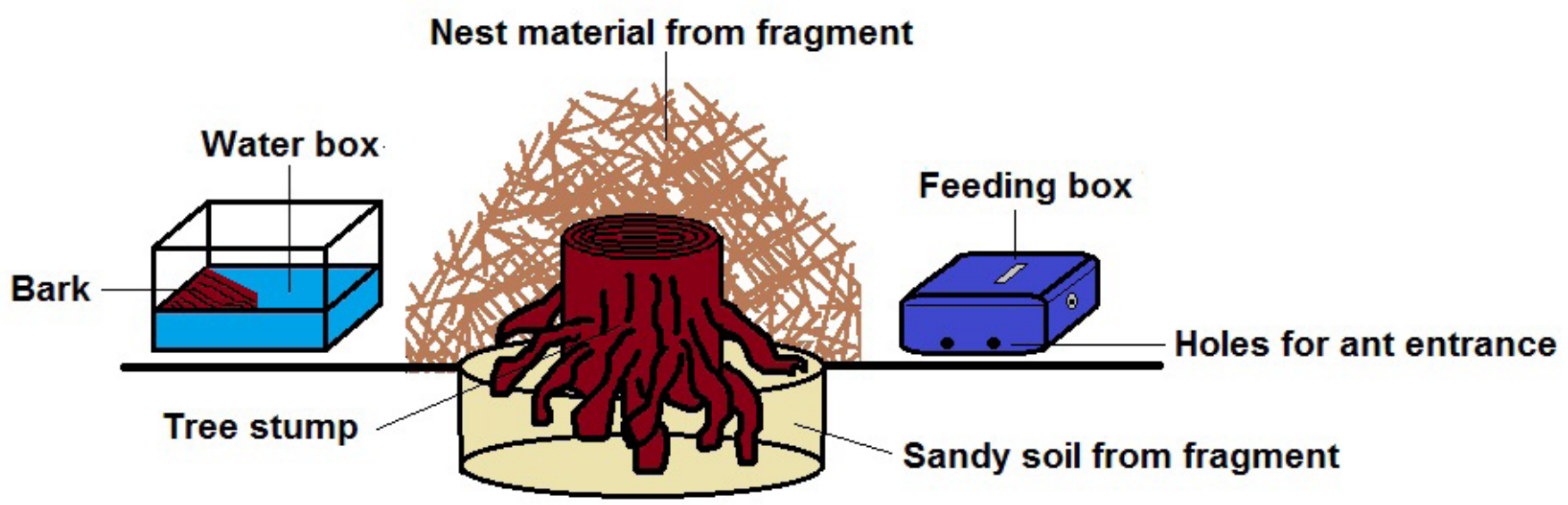

Fig 6. Artificial nest design for the transplantations to the organic and conventional Christmas tree plantations and the organic apple plantation. 
In this case, nest fragments were placed in another area of the plantation and placed on the ground as the holes prepared for the fragments were filled with water due to heavy rain that spring. The spacing between nests was $20-25 \mathrm{~m}$. These fragments were not fed protein, but had ad libitum sugar supplied during the summer. In addition, conifer needles were provided nearby as supplementary nest material. Otherwise, the fragments were prepared as in the previous year.

To assess the survival/activity of artificial and ant-built nests, we regularly counted the number of ants at the nest surfaces from April to October on sunny days between 12:00 and 13:00. A nest was considered active only if more than 20 ants were observed on the nest during the surveys.

To test the ants' potential as biocontrol agents we monitored the number of winter moth larvae (Operopthera brumata [Geometridae] - a pest of apple trees and other fruits and berries) on four varieties of apple trees (Holsteiner Cox, Alkmene, Angold and Resista) in 2015. To attract ants to apple trees a sugar feeder was mounted with a metal wire to each of 34 trees at a height of approximately $1.2 \mathrm{~m}$. Feeders were made from a $50 \mathrm{ml}$ centrifuge tube that was filled with $60-80 \mathrm{~g}$ sugar dough. Five holes $(\varnothing=4 \mathrm{~mm})$ were made in the lid of each tube to allow ants access to the sugar and to keep out larger animals. Trees with sugar feeders were selected by dividing each row of trees into four equally long segments (except one row with few trees that was divided into two segments). Within each segment, one tree was then randomly selected as a sugar tree. The 34 sugar trees were each paired with a neighboring control tree of similar appearance. Ants were excluded from control trees by a sticky barrier (OecoTak A5, Oecos) applied around the trunk of the tree. All remaining trees in the plot were accessible to ants, but without sugar feeders. Among the 34 tree pairs, 16 pairs were selected in the rows closest to the ant nests. On these 16 pairs of trees the number of ants and the number of $O$. brumata were counted on all trees on three dates during spring and early summer $(10 / 5,27 / 5$ and 5/6). Ants were counted by inspection of the entire tree, whereas the number of larvae was only counted on two randomly chosen side branches (one upper and one lower) per tree. The effect of the average number of ants per tree (average of the counts on the three dates) on the numbers of larvae counted per tree on each of the first two dates (no larvae were found on 5/6) were subsequently tested.

The observed number of larvae were assumed to be distributed according to a zero-inflated negative binomial distribution, and analyzed in a Bayesian statistical framework using R-INLA with default prior settings (Rue et al., 2009). The average number of observed ants were treated as a continuous explaining factor.

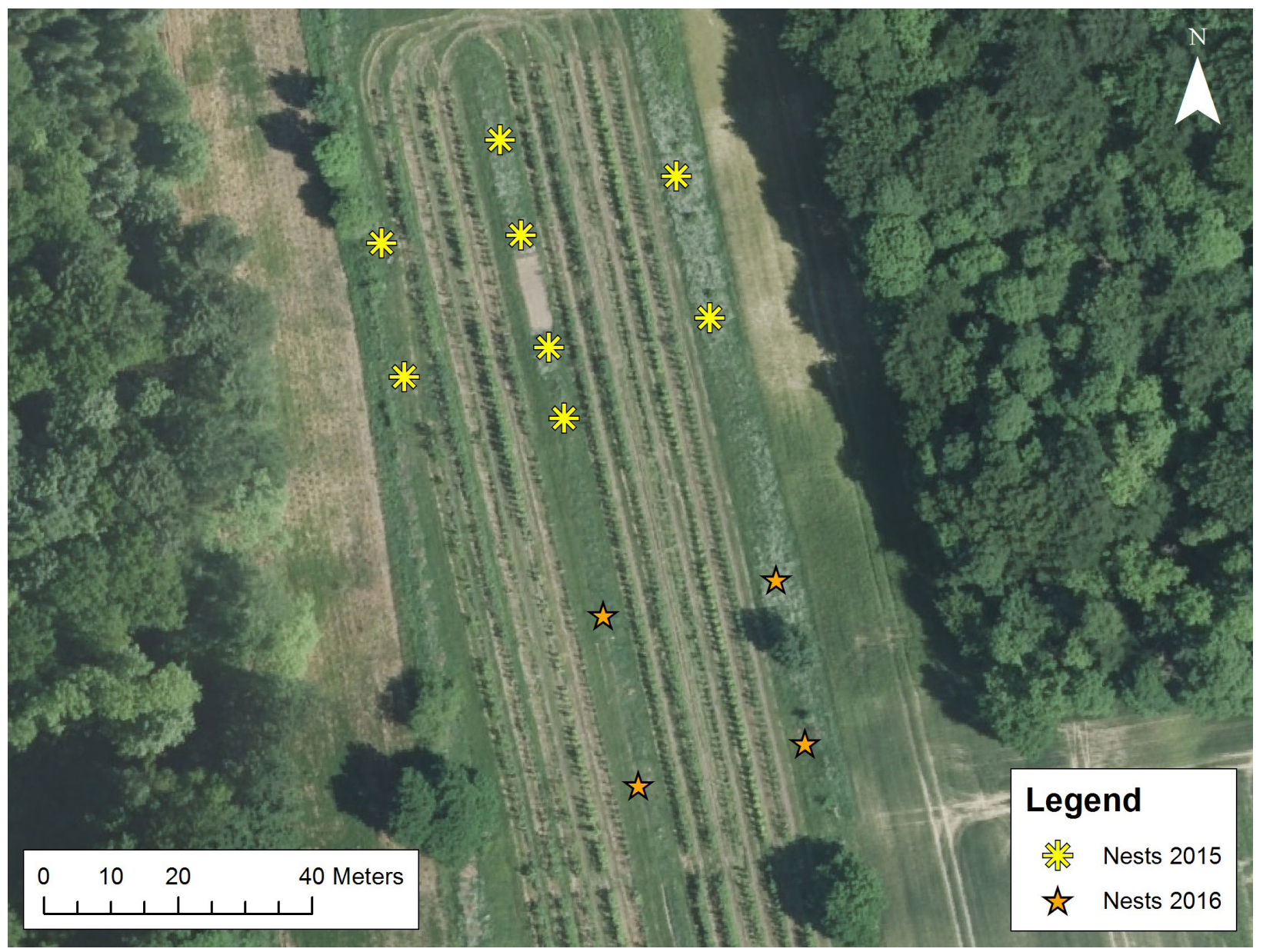

Fig 7. The organic apple tree plantation. Asterisks indicate the positions of the artificial transplant nests from 2015, stars indicate the positions of the artificial transplant nests from 2016. 


\section{Results}

Conifer seedling plot

Most of the fragments transplanted during the first transplantation abandoned their artificial nest within the first month. After 28 days, 23 of the 30 fragments were totally abandoned with the remaining seven fragments considered inactive due to the low ant activity at the nest surface $(<20$ ants). Workers were seen carrying brood up to $50 \mathrm{~m}$ from artificial nests to newly constructed nests in the surroundings and were also observed to transport brood between the new nests. As a result, 11 new ant-built nests were active after the 28 days. Inspection of these nests revealed that they were all built around pieces of wood such as, e.g., tree trunks. Also, we observed that the artificial nests were wet inside after the rain, whereas this was not the case with the nests constructed by the ants themselves. These observations led to the development of the second type of artificial nest design (see Methods) used in a second transplantation to the same site.

The second transplantation (the 11 new ant-built nests from the seedling plot plus 12 nest fragments from the same donor colony), using the second type of artificial nests, also resulted in an abandonment of most nests within a short time. After eight days, 14 of the 23 nests were totally abandoned with the remaining nests considered inactive given that fewer than 20 ants were present on the nest surface. The artificial nests were observed to be wet inside after the rain, very likely because the ants could not settle the needles properly in the deep laundry baskets. Again, the ants built new nests in the vicinity of the artificial nests. Twenty-one new ant built nests were active five days after the transplantation, but 10 of them were abandoned six weeks later. At the beginning of autumn (01-09-2014), 15 ant built nests were active but in the following spring (29-04-2015), this number had decreased to seven. None of the artificial nests were active during the autumn or in the following spring.

\section{Christmas tree plantations}

In the two Christmas tree plantations, all colonies stayed in the artificial nests until the following spring. Merging of colonies (ants moving from their original fragment to a neighboring fragment) was not observed in the organic plantation whereas ants migrated between fragments in the conventional plantation during the summer period. As a result, some fragments were abandoned here; only five of the original eight fragments were active in the late summer (12-08-2015) and again in the following spring (01-04-2016). In the organic Christmas tree plantation, all fragments were active until, and including, the following spring (01-04-2016).

Table 1. Data on transplantations by plantation type.

\begin{tabular}{|c|c|c|c|c|c|c|}
\hline \multirow[b]{2}{*}{ Year of transplantation } & \multicolumn{2}{|c|}{$\begin{array}{l}\text { Conifer seedling } \\
\text { plantation }\end{array}$} & \multirow{2}{*}{$\begin{array}{l}\text { Christmas tree } \\
\text { plantation - } \\
\text { organic } \\
2015\end{array}$} & \multirow{2}{*}{$\begin{array}{l}\text { Christmas tree } \\
\text { plantation - } \\
\text { conventional } \\
2015\end{array}$} & \multicolumn{2}{|c|}{ Apple plantation - organic } \\
\hline & 2014 & 2014 & & & 2015 & 2016 \\
\hline Donor colony identity & 1 & 1 & 1 & 2 & 2 & 2 \\
\hline \# of donor mounds used & 1 & 1 & 1 & 1 & 1 & 1 \\
\hline \# of fragments & 30 & $12+11$ & 8 & 8 & 8 & 4 \\
\hline Fragment size (L) & $26-42$ & 36 & 90 & 90 & 90 & 180 \\
\hline Distance between fragments (m) & 10 & 10 & $>25$ & $15-20$ & $15-20$ & $20-25$ \\
\hline \multicolumn{7}{|l|}{ Type of artificial nest design } \\
\hline Laundry basket in soil & $\mathrm{x}$ & $\mathrm{x}$ & & & & \\
\hline Hole in soil & & & $\mathrm{x}$ & $\mathrm{x}$ & $\mathrm{x}$ & \\
\hline On top of soil & & & & & & $\mathrm{x}$ \\
\hline Sand from donor colony & & $\mathrm{x}$ & $\mathrm{x}$ & $\mathrm{x}$ & $\mathrm{x}$ & $\mathrm{x}$ \\
\hline Bark on surface & & $\mathrm{x}$ & & & & \\
\hline Wood & & $\mathrm{x}$ & $\mathrm{x}$ & $\mathrm{x}$ & $\mathrm{x}$ & $\mathrm{x}$ \\
\hline Type of wood used in fragment & No wood & From forest & $\begin{array}{l}\text { From forest } \\
\text { and marked by } \\
\text { donor nest }\end{array}$ & $\begin{array}{l}\text { From forest } \\
\text { and marked by } \\
\text { donor nest }\end{array}$ & $\begin{array}{l}\text { From forest } \\
\text { and marked by } \\
\text { donor nest }\end{array}$ & $\begin{array}{l}\text { From forest } \\
\text { and marked by } \\
\text { donor nest }\end{array}$ \\
\hline Did ants build new nests? & Yes & Yes & No & No & No & No \\
\hline $\begin{array}{l}\text { Active nests in following autumn } \\
\text { (fragments/ant-built nests) }\end{array}$ & & $0 / 15$ & $8 / 0$ & $7 / 0$ & $5 / 0$ & $4 / 0$ \\
\hline $\begin{array}{l}\text { Active nests in following spring } \\
\text { (fragments/ant-built nests) }\end{array}$ & & $0 / 7$ & $8 / 0$ & $5 / 0$ & $5 / 0$ & $4 / 0$ \\
\hline Colony merging & Yes & Yes & No & Yes & Yes & No \\
\hline
\end{tabular}




\section{Apple plantation}

In the apple plantation, all the colonies also stayed in the artificial nests throughout the whole surveillance period. This was the case both for the 2015 and the 2016 transplantation. However, in 2015, ants merged and moved back and forth between the artificial nests so that activity differed among nests over the summer. In the autumn (1509-2015) and again in the following spring (08-04-2016) only five out of the original eight fragments were active. During the second transplantation, though, no merging between colonies was observed and all four fragments were active up to and including the following spring (09-03-2017).

On May 10, the number of winter moth larvae was significantly negatively correlated with the average number of ants counted on the Angold trees (Table 2). This was also the case on May 27, in this case both on Angold and Holsteiner cox trees (Figure 8). On the other apple varieties, the number of larvae did not correlate significantly with the average number of ants.

Table 2. The marginal posterior distributions of $\Delta \mu=\mu_{\text {ants }}-\mu_{\text {no ants }} \Delta \mu=\mu_{\text {ants }}-\mu_{\text {no ants }}$ summarized by their $2.5 \%$, $5 \%$, $50 \%, 95 \%$ and $97.5 \%$ percentiles. The effect of ants on the two first responses are considered two-tailed significant at the 5\% level as the quantiles within each response do not overlap 0, and one-tailed significant at the third response (Holsteiner Cox 27/5) as only the upper $97.5 \%$ overlap 0 .

\begin{tabular}{llccccccc}
\hline Response & Variety & mean & sd & $\begin{array}{c}2.5 \% \\
\text { quantile }\end{array}$ & $5 \%$ quantile & $\begin{array}{c}50 \% \\
\text { quantile }\end{array}$ & $\begin{array}{c}95 \% \\
\text { quantile }\end{array}$ & $\begin{array}{c}97.5 \% \\
\text { quantile }\end{array}$ \\
\hline Larvae & & & & & & & & \\
$10 / 52015$ & Angold & -1.48 & 0.74 & -3.12 & -2.81 & -1.41 & -0.4 & -0.23 \\
$27 / 52015$ & Angold & -0.79 & 0.4 & -1.65 & -1.5 & $-0-78$ & -0.17 & -0.056 \\
$27 / 52015$ & Holsteiner Cox & -1.12 & 0.74 & -2.76 & -2.46 & -1.05 & -0.037 & 0.13 \\
\hline
\end{tabular}

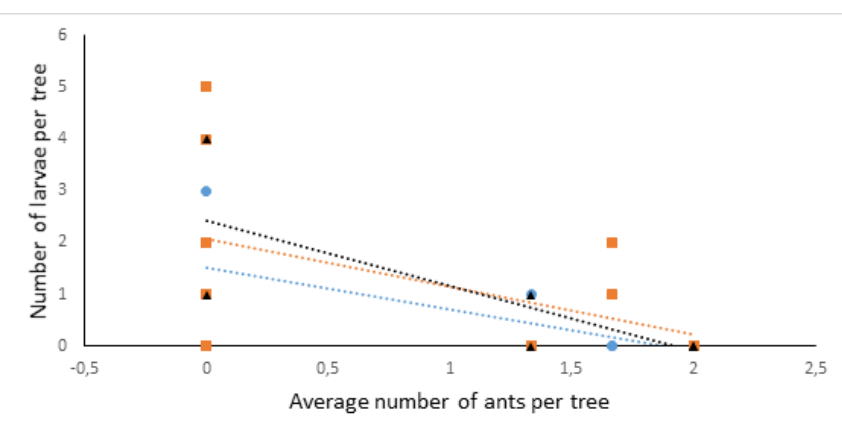

Fig 8. Winter moth larvae by ants and apple variety. Blue circles and hatched line shows Angold trees on May $10(\mathrm{~N}=16$ trees), orange squares and hatched line shows Angold on May 27 ( $\mathrm{N}=16$ trees), and black triangels and hatched line shows Hosteiner Cox on May 27 ( $\mathrm{N}=8$ trees). Lines for illustrative purpose are based on simple linear regressions.

\section{Discussion}

We successfully transplanted $F$. polyctena mound fragments from a mature conifer forest into two Christmas tree and one apple plantation and partly successfully into a seedling forest plot. Ants survived in their nests the entire surveillance period (at least one year) in all plantation types. In some cases, they moved away from their transplant positions to build new nests, or moved from one fragment to another to leave some fragments inactive. Based on our observations, though, it seems likely that ant movements may be controlled via the use of (i) an adequate size of the artificial nests, (ii) a minimum distance between artificial nests and (iii) the incorporation of sand and scent marked wood pieces from donor mounds to imitate the structure of natural occurring wood ant nests. We furthermore show that the transplanted ants were able to reduce numbers of an important apple pest species.

Our observations showed that wood ants can tolerate a wide range of plantation habitats. They persisted in habitat types spanning from young stands of familiar host species (conifers) to a highly managed apple plantation without conifer trees at all. Furthermore, the four colonies that were transplanted into the apple plantation in 2016 performed well despite being placed at the soil surface instead of being placed in an excavated hole. These colonies quickly excavated the soil under the nests. Also, they survived even though the underground part of their nests probably was flooded during a part of the winter and spring. During this period, we occasionally observed standing water at the soil surface close to the ant nests. Based on these results, we believe that $F$. polyctena may be transplanted into most types of perennial forests, fruit and berry plantations or even into annual crops. They thus have the potential to become applicable biocontrol agents in crops that suffer from pests that are attacked by these ants.

Controlling the position and activity of ant nests is of importance for plantation management if ants are to be used as biocontrol agents. First, it is important that the ants do not build nests in new locations as this may interfere with plantation management. If the ants nest in areas where mowing or other machinery operations are performed, their nests may be destroyed. Secondly, biocontrol is likely optimized when ants are kept at specific optimum densities as it has been recommended, e.g., with the use of weaver ants in biocontrol programs (Wargui et al., 2015). To maintain ants at specified densities, it is crucial that ant nests do not merge. 
We only observed the ants building new nests during the two transplantations in the conifer seedling plot (Table 1); in all other cases, the ants accepted the artificial nests. These two transplantations were also the only cases where we used laundry baskets and did not incorporate pieces of wood that had previously been marked by donor colonies. There was no doubt that a piece of wood in the nest was very important to the ants, as in all cases where the ants built new nests, these nests were built around a piece of wood in the surrounding area. Also, all donor mounds, when excavated, contained a tree stump. However, despite having supplied non-marked wood for the ants in the second transplantation, they preferred other non-marked wood pieces in the surrounding area. This suggests that other factors, such as wetness or nest collapse, may have been the reason for the abandonment of the nests. The artificial nests in the laundry baskets were found wet after both transplantations, whereas this was not the case when laundry baskets were not used. The laundry baskets may have hampered the ants in settling the needles in the artificial nests, and thus caused the lack of protection of the nests against the rain.

Regarding the movements of ants between artificial nests, this appeared to be hindered by a minimum size of the artificial nests or by a minimum distance between nests. The ants only remained active in all nests (no merging) in the organic Christmas tree plantation and in nests from the second transplantation into the apple plantation. In the former case, fragments were $90 \mathrm{~L}$ just as in the cases where merging did occur (conventional Christmas tree plantation and the first transplantation into the apple plantation), however, the distance between nests was increased to $>25 \mathrm{~m}$ compared to $15-20 \mathrm{~m}$ at the conventional Christmas tree plantation. In the second transplantation into the apple plantation, we increased the size of fragments to $180 \mathrm{~L}$. This stopped the abandonment of nests, compared to the previous year in the same plantation, where fragments were only half the size (90 L) and with only slightly longer between nests. Thus, artificial nests seemed to require a minimum spacing or a certain minimum population size for the ants to accept a location. Size in terms of individuals seemed to be more important than volume, given the nests that merged during the first transplantations did not seem to increase in volume, only in ant numbers. It should be noted that factors were not controlled during these studies as we e.g. worked in different plantations. Yet, our experiences suggest that adequate spacing ( $>25 \mathrm{~m}$ between nests) and/or large nest sizes (180 L per nest) may be required to avoid nest abandonment.

Our findings on nest volume and spacing are supported by other studies performed in forest habitats. Wellenstein (1973) was able to found $F$. polyctena nests with $30-300 \mathrm{~L}$ fragments but had the highest survival in fragments from 150$200 \mathrm{~L}$. Working on the same species Pisarski and Czechhowski (1990) found that artificial transplanted mounds with a spacing of 20-30 m but with a volume of only $50 \mathrm{~L}$ most often merged, resulting in much fewer active nests than originally transplanted. Similarly, Sorvari et al. (2014) found that mound fragments of $100 \mathrm{~L}$ in $F$. aquilonia was not adequate to prevent merging at a distance of $30 \mathrm{~m}$ between mounds, and Finnegan (1975) observed that $F$. lugubris colonies that were moved without any nest material was merging between nests even at a spacing of approximately $50 \mathrm{~m}$. Lastly, Bradley (1972) found that transplanted nests of $F$. obscuripes merged when spaced with $7 \mathrm{~m}$ between transplanted nests, whereas merging rarely occurred at spacings of $28 \mathrm{~m}$. In this study nest sizes were not provided.

In summary, we consider that adequate nest spacing and nest fragment sizes are critical for successful establishment of $F$. polyctena colonies. Further, we find that the addition of tree stumps to nest fragments are critical, whereas excavation of soil under the transplanted nest is not important.

Pests known to be attacked by $F$. polyctena are often defoliating outbreak pests including, e.g., species of sawflies, Totricidae, Geometridae and Lymantriidae (Adlung, 1966), but also damages by beetles may be reduced (Maňák et al., 2013). Controlled species include a number of important forest pests, e.g. well known pests in fruit and berry plantations such as Operophtera brumata (L.) and conifer pests such as Hylobius abietis (L.)(Sigsgaard et al., 2013; Maňák et al., 2013). In this current study, we observed the ants preying on $O$. brumata on the apple trees and we registered reduced numbers of this pest on two of the four apple varieties. Since wood ants are generalists that attack most insects as potential prey, we believe they may work as biocontrol agents in a number of crops. On the other hand, ants are also known to protect aphids that may increase in abundance when tended by ants (Way \& Khoo, 1992). This problem, however, may be addressed by feeding ants with sugar, as ants may neglect or even prey on otherwise tended aphids when having ad libitum access to sugar (Offenberg, 2001; Nagy et al., 2013). Presently, the plant protection industry and researchers are developing commercial sugar feeders and sugar solutions designed to break the mutualisms between ants and attended trophobionts in agriculture (Wäckers et al., 2017). However, more work is needed to assess services and disservices of wood ants before judging on their applicability as control agents.

In conclusion, and given the mutualism between ants and pest hemipterans can be handled, the transplantation of wood ant nests could be a future tool for organic and conventional horticulture. Not only are the ants able to survive in a variety of settings, but they are also portable in their mounds and can easily be moved into and out of plantations. They may thus be used prophylactically in permanent setups, or alternatively used short term to assist in reducing pests in plantations during severe outbreaks. Furthermore, they do not easily disperse, as do traditional more mobile (e.g. flying) beneficial arthropods used in open systems (Van Driesche et al., 2008). Being organized in large nest mounds and being resistant to fluctuations in microclimate wood ant nests are temporally and spatially reliable partners and could become valuable for biocontrol in open systems. 


\section{Acknowledgements}

This study was supported by the GUDP/ICROFS Organic RDD 2.2 project MothStop (34009-15-0984) and the GUPD project AntAid (34009-13-0599), both under the Ministry of Environment and Food of Denmark.

\section{Authors Contribution}

JS Nielsen contributed to fieldwork, conception, design, interpretation and to revisions of the manuscript. MG Nielsen contributed to fieldwork, conception, design and revisions of the manuscript. CF Damgaard performed the statistical analyses. J Offenberg drafted the manuscript and contributed to fieldwork, conception, design, and interpretation. All authors have approved the final version of the manuscript.

\section{Reference}

Adlung, K. G. (1966). A critical evaluation of the European research on use of red wood ants (Formica rufa group) for the protection of forests against harmful insects. Zeitschrift für Angewandte Entomologie, 57, 167-189. doi: 10.1111/j.1439-0418.1966.tb03822.x.

Bradley, G. A. (1972). Transplanting Formica obscuripes and Dolichoderus taschenbergi (hymenoptera: formicidae) colonies in jack pine stands of southeastern Manitoba. The Canadian Entomologist, 104, 245-249. doi: 10.4039/Ent104245-2.

Brandt , I. (2015). En million økologiske juletræer. Økologi \& Erhverv, pp. 4. Økologisk Landsforening, Denmark.

Calvo, F. J., Knapp, M., van Houten, Y. M., Hoogerbrugge, H. \& Belda, J. E. (2015). Amblyseius swirskii: What made this predatory mite such a successful biocontrol agent? Experimental and Applied Acarology, 65, 419-433. doi: 10.1007/s10493-014-9873-0.

Finnegan, R. J. (1975). Introduction of a predacious red wood ant, Formica lugubris (Hymenoptera-Formicidae), from Italy to Eastern Canada. Canadian Entomologist, 107, 1271-1274. doi: 10.4039/Ent1071271-12.

Gösswald, K. (1984). Übersiedlung der Gebirgswaldameise Formica lugubris Zett. (The Relocation of Formica lugubris). Zeitschrift fuer Angewandte Zoologie, 71, 193-214.

Gösswald, K. (1990). Die Waldameise. Band 2. Die Waldameise in Ökosystem Wald, ihr Nutzen und ihre Hege. AULA-Verlag Wiesbaden. doi: 10.1002/mmnd.19910380408.

Hajek, A. (2004). Natural Enemies: An introduction to biological control. Cambridge University Press, UK. doi: 10.1017/CBO9780511811838.

Jensen, K. L. \& Pedersen, E. (2015). Status og udvikling i dansk økologi i perioden 2005-2014. Økologiens bidrag til samfundsgoder: Vidensyntese 2015 (ed L. M. Jespersen). ICROFS.
Jonsson, M., Wratten, S. D., Landis, D. A. \& Gurr, G. M. (2008). Recent advances in conservation biological control of arthropods by arthropods. Biological Control, 45, 172-175. doi: 10.1016/j.biocontrol.2008.01.006.

Kilpeläinen, J., Punttila, P., Finér, L., Niemelä, P., Domisch, T., Jurgensen, M. F., Neuvonen, S., Ohashi, M., Risch, A. C. \& Sundström, L. (2008). Distribution of ant species and mounds (Formica) in different-aged managed spruce stands in eastern Finland. Journal of Applied Entomology, 132, 315-325. doi: 10.1111/j.1439-0418.2007.01244.x.

Maňák, V., Nordenhem, H., Björklund, N., Lenoir, L. \& Nordlander, G. (2013). Ants protect conifer seedlings from feeding damage by the pine weevil Hylobius abietis. Agricultural and Forest Entomology, 15, 98-105. Doi: 10.1111/j.1461-9563.2012.00597.x.

Nagy, C., Cross, J. V. \& Markó, V. (2013). Sugar feeding of the common black ant, Lasius niger (L.), as a possible indirect method for reducing aphid populations on apple by disturbing ant-aphid mutualism. Biological Control, 65, 24-36. Doi: 10.1016/j.biocontrol.2013.01.005.

Offenberg, J. (2001). Balancing between mutualism and exploitation: The symbiotic interaction between Lasius ants and aphids. Behavioral Ecology and Sociobiology, 49, 304310. doi: $10.1007 / \mathrm{s} 002650000303$.

Offenberg, J. (2015). Ants as tools in sustainable agriculture. Journal of Applied Ecology, 52, 1197-1205. doi: 10.1111/1365-2664.12496.

Paulson, G. S. \& Akre, R. D. (1992). Evaluating the effectiveness of ants as biological control agents of pear psylla (Homoptera, Psyllidae). Journal of Economic Entomology, 85, 70-73. doi: 10.1093/jee/85.1.70.

Pisarski, B. \& Czechowski, W. (1990). The course of artificial colonization of red wood ants in the Gorce National Park. Memorabilia Zoologica, 44, 37-46.

Rue, H., Martino, S. \& Chopin, N. (2009). Approximate Bayesian inference for latent Gaussian models using integrated nested Laplace approximations. Journal of the Royal Statistical Society, Series B, 71, 319-392.

Sigsgaard, L., Philipsen, H., Jakobsen, H. B. \& Korsgaard, M. (2013). Mechanical and biological control of winter moth, tortricids and Lampronia capitella in black and red currant. University of Copenhagen, Faculty of Science, Department of Plant and Environmental Sciences, Copenhagen.

Sorvari, J., Huhta, E. \& Hakkarainen, H. (2014). Survival of transplanted nests of the red wood ant Formica aquilonia (Hymenoptera: Formicidae): The effects of intraspecific competition and forest clear-cutting. Insect Science, 21, 486-492. doi: 10.1111/1744-7917.12043.

Stockan, J. A. \& Robinson, E. J. H. (2016). Wood ant ecology 
and conservation. Cambridge University Press, United Kingdom. doi: 10.1017/CBO9781107261402.

Storer, A. J., Jurgensen, M. F., Risch, A. C., Delisle, J. \& Hyslop, M. D. (2008). The fate of an intentional introduction of Formica lugubris to North America from Europe. Journal of Applied Entomology, 132, 276-280. doi: 10.1111/j.1439-0418.2008.01275.x.

Strandberg, B., Bruus, M., Krogh, P. H., Ravnskov, S., Langer, V., Hansted, L., Sigsgaard, L., Ahrenfeldt, E. J. \& Andreasen, L. (2015). Natur og biodiversitet. Økologiens bidrag til samfundsgoder: Vidensyntese 2015 (ed L. M. Jespersen). ICROFS.

Van Driesche, R., Hoddle, M. \& Center, T. (2008). Control of pests and weeds by natural enemies: An introduction to biological control. Blackwell Publishing Ltd, Singapore. doi: 10.1653/024.092.0237.

Vandermeer, J., Perfecto, I. \& Philpott, S. (2010). Ecological complexity and pest control in organic coffee production: Uncovering an autonomous ecosystem service. Bioscience, 60, 527-537. doi: 10.1525/bio.2010.60.7.8.

Wargui, R., Offenberg, J., Sinzogan, A., Adandonon, A., Kossou, D. \& Vayssières, J. F. (2015). Comparing different methods to assess weaver ant abundance in plantation trees. Asian Myrmecology, 7, 159-170. doi: 10.20362/am.007017

Way, M. J. \& Khoo, K. C. (1992). Role of ants in pestmanagement. Annual Review of Entomology, 37, 479-503. doi: 10.1146/annurev.en.37.010192.002403.

Wellenstein, G. (1952). Zur Ernahrungsbiologie der Roten Waldameise. Pflanzenschutz, 59, 430-451.

Wellenstein, G. (1973). The development of artificially founded colonies of hill-building red wood ants of the Formica rufa-group in south-western Germany. EPPO Bulletin, 2, 2334. doi: 10.1111/j.1365-2338.1973.tb02098.x.

Wielgoss, A., Tscharntke, T., Rumede, A., Fiala, B., Seidel, H., Shahabuddin, S. \& Clough, Y. (2014). Interaction complexity matters: Disentangling services and disservices of ant communities driving yield in tropical agroecosystems. Proceedings of the Royal Society B: Biological Sciences, 281. doi: $10.1098 / \mathrm{rspb} .2013 .2144$.

Wäckers, F. L., Alberola, J. S., Garcia-Mari, F. \& Pekas, A. (2017). Attract and distract: Manipulation of a foodmediated protective mutualism enhances natural pest control. Agriculture, Ecosystems \& Environment, 246, 168-174. doi: 10.1016/j.agee.2017.05.037. 